\title{
ЦИТОТОКСИЧЕСКАЯ АКТИВНОСТЬ НЕКОТОРЫХ КАРБОЦИКЛИЧЕСКИХ ЗАМЕЩЕННЫХ 1,3-ДИОКСОЛАНОВ
}

\section{Ю.Г. Борисова, Ш.Ш. Джумаев, Г.З. Раскильдина, С.С. Злотский}

ФГБОУ ВО «Уфимский государственный нефтяной технический университет», 450064, Россия, г. Уфа, ул. Космонавтов, д. 1.

DOI: 10.19163/MedChemRussia2021-2021-497

E-mail: yulianna_borisova@mail.ru

В продолжение ранее описанных работ [1-3], из этиленгликоля 1 и карбонильных соединений 2a, б были получены циклические ацетали $3 \mathrm{a}, \boldsymbol{6}$, которые использовались для синтеза карбоциклических замещенных 1,3-диоксоланов 4а, 6 (схема 1).<smiles>C=CC(=O)CCC(O)CCc1ccccc1/C=C/C=O</smiles>

Схема 1.

В результате исследования влияния веществ на жизнеспособность клеток показано, что соединения 3а, б не проявляют цитотоксической активности, однако 2-(2,2-дихлор-3-фенилциклопропил)-1,3-диоксолан 4а и 2-(2,2-дихлорциклопропил)-2-этил-1,3-диоксолан 46 обладают цитотоксическими свойствами в отношении клеток линии HEK293, SH-SY5Y, Jurkat, HepG2, MCF-7 и A549.

Исследования выполнены при финансировании гранта Президента РФ для государственной поддержки молодых российских ученых - кандидатов наук и докторов наук no № MK-1689.2020.3.

\section{Литература}

[1] Hatice Başpınar Küçük, Ayşe Yusufoğlu, Emel Mataracı and Sibel Döşler. Molecules. 2011. 16. 6806-6815.

[2] Раскильдина Г.З., Яковенко Е.А., Мрясова Л. М., Злотский С.С. Известия высших учебных заведений. Серия химия и химическая технология. 2019. 62.1.91-97.

[3] Raskil'dina G.Z., Kuz'mina U.S., Borisova Y.G., Zlotskii S.S. Pharm Chem. 2020. 54. 909-913. DOI: 10.1007/s11094-020-02295-8. 